Article

\title{
The Uyghur Minority in China: A Case Study of Cultural Genocide, Minority Rights and the Insufficiency of the International Legal Framework in Preventing State-Imposed Extinction
}

\section{Ciara Finnegan}

Department of Law, Maynooth University, Maynooth, Co. Kildare, Ireland; ciara.finnegan.2014@mumail.ie

Received: 28 November 2019; Accepted: 7 January 2020; Published: 11 January 2020

\begin{abstract}
Raphael Lemkin, the man who founded the term 'genocide,' did so with a view to protecting not only physical beings from systematically imposed extinction, but also protecting their cultures from the same fate. However, in the wake of the atrocities and bloodshed of WWII, cultural genocide was omitted from the 1948 Genocide Convention, and as a result, does not constitute an international crime. This omission has left a lacuna in international law which threatens minority groups. Not a threat of loss of life but rather loss of the culture that distinguishes them and identifies them as a minority. Powerful States with indifferent attitudes towards their international obligations face no significantly harsher punishment for cultural genocide than they do for other human rights transgressions. Consequently, cultural genocide continues as minority cultures are rendered extinct at the hands of States. The Case Study of this article investigates the present-day example of the Uyghur minority in China and analyzes whether this modern cultural genocide can pave the way for the recognition of cultural genocide as an international crime or whether the Uyghur culture will become a cautionary tale for minorities in the future.
\end{abstract}

Keywords: uyghur; uighur; minority rights; cultural genocide; raphael lemkin; china; china human rights; china counter-terrorism; vocational education centres; international law

\section{Introduction}

"A people without the knowledge of their past history, origin and culture is like a tree without roots." ${ }^{1}$

-Marcus Garvey

Garvey illustrates in this quote the importance of culture to current and future generations of minority peoples. Culture and knowledge of cultural heritage anchor a minority firmly within their identity and allow them to carry out their lives as a community distinct from a majority population, be it due to their ethnic, religious or linguistic characteristics.

Therefore, if this core culture is stripped from a minority people, in the sense that they are left to physically survive but their culture has been forcibly destroyed, they are essentially a shell of their former selves. This practice, known as cultural genocide, is often employed by States' governments, representative of the majority, in order to extinguish the minority cultures and create a culturally homogenous State. This is currently the situation of the Uyghur minority in China, which will form the case study of this article.

\footnotetext{
1 While paraphrased by Garvey, the quote originated in (Seifert 1938, p. 5).
} 
This article aims to demonstrate that the current international legal framework falls short of protecting minority populations from the risk of cultural genocide and suggests that the expansion of the internationally-recognized definition of genocide could be a solution to the issue. While there are minority rights protections enshrined in international law, cultural genocide does not fall under the jurisdiction of the International Criminal Court (hereinafter referred to as the ICC) and, as a result, does not carry a criminal prosecution. Consequently, States that do not comply with minority and human rights obligations do not face serious repercussions if they grievously breach these obligations through implementing policies of cultural genocide. This lack of serious consequences for the breaching of minorities' integral right to their respective cultures constitutes a failing in the minority protection granted by the current international legal framework. This article will recommend the expansion of the concept of genocide in order to bolster the protection of these minority cultures.

The methodology implemented to achieve this article's aim will be that of descriptive-normative analysis of the international legal instruments concerning genocide and minority protection. This mode of research will provide "important grounding" (Kennedy 2016, p. 37) for both the Case Study of the Uyghur Muslims in China in Section 5 and the recommendations for a way forward for the legal arena to deal with both the on-going Uyghur situation and cultural genocide in general in Section 6.

In this article, the arguments will be structured by initially outlining the concept of cultural genocide and its absence from International Criminal Law (hereinafter referred to as ICL). The importance of culture with respect to the protection of minority rights will then be elaborated on. The context surrounding the situation of the Uyghur minority in China will be discussed with respect to the assimilationist policies that this minority has faced throughout history. The Case Study will then outline the cultural genocide of the Uyghur minority which is currently on-going in China. Finally, the prospect of a way forward for the protection of the Uyghur minority from this cultural genocide, as well as the protection of other minorities in the future, will be discussed.

\section{Cultural Genocide}

Genocide, the term which combines "the Greek word 'genos' or genus' meaning race, and the Latin word 'cide' meaning killing" (Hon 2013, p. 3), was first constructed by Polish lawyer, Raphael Lemkin, in 1943. However, it was earlier than this point of definition that Lemkin "advocated the recognition of the systematic and organized destruction of the ... cultural heritage of a collectivity" (Negri 2013, p. 1). While coining the term 'genocide,' Lemkin considered primarily the destruction endured by the Armenian population at the hands of the Ottoman government during World War I.

Despite this intention, due to the time at which the term emerged, it became embedded in the legal consciousness when Lemkin applied it to the Holocaust that Nazi Germany had carried out throughout World War II. In his book, 'Axis Rule in Occupied Europe' (Lemkin 1944), Lemkin outlined genocide broadly as constituting "political, social, cultural, economic, biological, physical, religious, and moral genocide" (Novic 2016, p. 18). Thus, Lemkin envisaged a definition of genocide that encompassed not just the physical killing of the members of a group, but also, among others, the destruction of a group's culture through "the prohibition of the use of a local language and schools, the restriction or ban of artistic, literary and cultural activities" and the destruction of cultural institutions (Hon 2013, p. 7).

It is this broad envisagement of genocide that Lemkin wished to prohibit in the United Nations Economic and Social Council (ECOSOC) negotiations for the Genocide Convention resulting from the adoption of Resolution 96(1) related to 'The crime of genocide' 2 by the United Nations General Assembly in December 1946. Upon adoption of this resolution, the United Nations General Assembly defined genocide as "the denial of the right of existence of entire human groups" that "shocks the conscience of mankind, results in great losses to humanity in the form of cultural and other contributions

2 United Nations General Assembly. “The Crime of Genocide." A/RES/96. 11 December 1946. 
represented by these human groups." ${ }^{3}$ Thus, it is clear that at the outset of the negotiation process, the loss of culture was central to the concept of genocide.

In the first process of negotiations, Lemkin's Draft Article II outlined a comprehensive definition of cultural genocide. This definition included "forcible transfer of children ... forced and systematic exile of individuals ... prohibition of the use of the national language ... systematic destruction of books printed in the national language or of religious works or prohibition of new publications; or...systematic destruction of historical or religious monuments" (Novic 2016, p. 25). While none of these proposed acts would result in the physical extinction of a group, they would have a detrimental effect on a group's culture. Thus, the definition highlighted the fact that cultural genocide "does not literally annihilate communities, but destroys their culture and thereby their identity" (Negri 2013, p. 5).

However, it was the absence of physical violence towards a group that caused disagreement among the negotiating parties. Many States believed that "the gap between mass murder and the closure of libraries was just too large" (Hon 2013, p. 11) to justify the inclusion of cultural genocide in the definition of a crime which warranted prohibition because it "shocks the conscience of mankind."4 Therefore, despite the fact that the concept of cultural genocide had been the center of discussions "in all drafting sessions" (Hon 2013, p. 10), it was finally decided to "delete the cultural genocide provision from the Genocide Convention" (Novic 2016, p. 27).

As a result, the accepted definition of genocide, as enshrined in international law in Article II of the Convention on the Prevention and Punishment of the Crime of Genocide 1948, includes:

"any of the following acts committed with intent to destroy, in whole or in part, a national, ethnical, racial or religious group, as such:

(a) Killing members of the group;

(b) Causing serious bodily or mental harm to members of the group;

(c) Deliberately inflicting on the group conditions of life calculated to bring about its physical destruction in whole or in part;

(d) Imposing measures intended to prevent births within the group;

(e) Forcibly transferring children of the group to another group." ${ }^{15}$

The only act of cultural genocide retained in this definition was the forcible transfer of children from one group to another, constituting the last remnant of Lemkin's cultural genocide definition in international law. Furthermore, at the Diplomatic Conference of Plenipotentiaries on the Establishment of an International Criminal Court in 1998, when the crime of genocide that could be prosecuted by the ICC was defined, it was "decided to use the language as in the Convention" (Hon 2013, p. 23). Thus, the definition of genocide in Article 6 of the Rome Statute of the International Criminal Court ${ }^{6}$ mirrors the definition of the Genocide Convention, which arguably constituted "a missed opportunity for the international community to criminalize the international destruction, 'in whole or in part,' of a nation's culture and identity-cultural genocide" (Hon 2013, pp. 52-53).

As a result, there is a gap in ICL that "prevents criminal tribunals from punishing acts of cultural genocide unrelated to the physical destruction of the members of the targeted group" (Negri 2013, p. 5). Hon noted that this "lack of appreciation-legal and societal-for the destructive effect that obliteration of a cultural identity has on its people" (Hon 2013, p. 5) has led to the marginalization of the concept. Upon omission from the formal definition of genocide, States highlighted the fact that cultural genocide would be "best dealt with in 'the sphere of protection of minorities' or human rights

\footnotetext{
United Nations General Assembly 1946, preamble.

United Nations General Assembly 1946, preamble.

"Convention on the Prevention and Punishment of the Crime of Genocide," opened for signature 1948. United Nations Treaty Series vol. 78 , p. 277, art II.

6 United Nations General Assembly. "Rome Statute of the International Criminal Court (last amended 2010)." ISBN No. 92-9227-227-6. 17 July 1998, art 6.
} 
law" (Hon 2013, p. 11). Despite developments in these areas of international law in the interim, a ban on cultural genocide has not been established in any human rights instrument that carries the same level of severity or accountability as that of an act of genocide that falls within the 1948 definition.

While the narrow ambit of the definition of genocide, restricted to specific physical actions, was aimed to set the standard for the 'crime of crimes' as only constituting the worst attacks on the groups that collectively make up humanity, the omission of cultural genocide is regarded as the definition's downfall. As Negri highlights, "the present understanding of genocide preserves the body of the group but allows its very soul to be destroyed" (Negri 2013, p. 8) by allowing cultural genocide to slip through the gap in ICL and continue without international prosecution. This gap in ICL results in a lack of protection for many groups, especially minorities, as the next section will discuss.

\section{Cultural Genocide and Minorities}

The presence of a common culture is an integral characteristic of a minority group and it is for this reason that cultural genocide poses such a threat to the continued existence of minority groups on a global scale. While no specific definition of 'culture' is provided in international law, its significance is evident from its inclusion in various international human rights instruments. This section will describe how the significance of culture applies in the case of minority groups and how the protection of minority cultures is currently enshrined in the international legal framework.

The right of every person to "participate in the cultural life of the community, to enjoy the arts and to share in scientific advancement and its benefits" ${ }^{\prime 7}$ is enshrined in Article 27(1) of the 1948 Universal Declaration of Human Rights (hereinafter referred to as the UDHR). Similarly, this right to participate in cultural life is also included in Article 15 of the International Covenant on Economic, Social and Cultural Rights (hereinafter referred to as the ICESCR). ${ }^{8}$ Furthermore, the United Nations Educational, Scientific and Cultural Organisation (hereinafter referred to as UNESCO) Universal Declaration on Cultural Diversity, although not a binding instrument, elaborates on the importance of a person's culture. Article 4 of this instrument outlines that "[ $t]$ he defence of cultural diversity is an ethical imperative, inseparable from respect for human dignity." ${ }^{\prime 9}$ These instruments highlight the necessary role that respect for and access to a person's culture have on their human dignity and fundamental rights.

This recognition of the importance of culture for all persons is specifically tailored to the case of minority peoples in Article 27 of the International Covenant on Civil and Political Rights (hereinafter referred to as the ICCPR). Article 27 states that "[i]n those States in which ethnic, religious or linguistic minorities exist, persons belonging to such minorities shall not be denied the right, in community with the other members of their group, to enjoy their own culture, to profess and practise their own religion, or to use their own language." 10 This provision, which currently constitutes the main article that provides for minority rights in international law, demonstrates how the maintenance of culture is central to the continued functioning and existence of minority life.

Furthermore, UNESCO also created instruments that highlight the significance of the protection of the cultural heritage of groups. As early as the 1970s, UNESCO recognized the significance of tangible cultural heritage in the Convention Concerning the Protection of the World Cultural and Natural Heritage 1972. ${ }^{11}$ More significant still for many minorities was the implementation of the

7 United Nations General Assembly. “Universal Declaration of Human Rights.” 10 December 1948. 217 A (III), art 27(1).

8 United Nations General Assembly. "International Covenant on Economic, Social and Cultural Rights," opened for signature 16 December 1966. United Nations Treaty Series, vol. 993, p. 3, art 15.

9 United Nations Educational, Scientific and Cultural Organisation (UNESCO). "UNESCO Universal Declaration on Cultural Diversity." 2 November 2001, art 4.

10 United Nations General Assembly. "International Covenant on Civil and Political Rights," opened for signature 16 December 1966. United Nations Treaty Series, vol. 999, p. 171, art 27.

11 United Nations Educational, Scientific and Cultural Organisation (UNESCO). “UNESCO Convention Concerning the Protection of the World Cultural and Natural Heritage." 16 November 1972. 
UNESCO Convention for the Safeguarding of the Intangible Cultural Heritage 2003. ${ }^{12}$ Article 2 of the 2003 Convention recognizes the significance of protecting the 'intangible cultural heritage' of groups, which may consist of "the practices, representations, expressions, knowledge, skills."13 These UNESCO Conventions recognize that "the destruction of both tangible (such as places of worship) as well as intangible (such as language) cultural structures" (Bilsky and Klagsbrun 2018) would have devastating effects on the continued existence of minority populations. It is these elements of cultural heritage and existing cultural practices that, although protected by international legal instruments, are most often the targets of cultural genocide practices.

The bond between culture and minority groups included in all of the above-mentioned instruments clearly demonstrates that the practice of cultural genocide is intrinsically linked to minority groups. Lemkin himself emphasized that "the essence of genocide was cultural-a systematic attack on a group of people and its cultural identity; a crime directed against difference itself" (Bilsky and Klagsbrun 2018). It is this difference in culture which separates and distinguishes a minority group from the majority population and often is targeted in the one of the most severe forms of minority discrimination-cultural genocide. It is this undeniable link between minorities and cultural genocide which was used by delegates to justify the exclusion of cultural genocide from the 1948 Genocide Convention, who, as noted above, stated that it was a minority issue warranting a separate instrument (Hon 2013, p. 11).

Unfortunately, such proposed instrument on cultural genocide never materialized and the protection of the culture of minority groups is limited to the articles of the human rights instruments outlined above. Thus, the protection provided by these instruments, albeit limited, extends to the Uyghur minority in China, which constitutes the Case Study of this article. However, it is noted that the "authoritarian system" of government in power in China merely pays "lip service" to international human rights obligations (Rossabi 2014, p. 404).

While China signed the ICCPR, the Chinese government never ratified the instrument, and thus, its protection does not apply to the Uyghur minority located there. Despite this, minority rights have been enshrined in the Chinese Constitution since the Temporary Constitution of the Republic of China of 1911 (Bai 2004, p. 449). China is constitutionally recognized as "a unitary multi-national State created jointly by the people of all its nationalities" 14 with a history marred by the struggle "to safeguard the unity of the nationalities." ${ }^{15}$ Furthermore, Article 4 of the current Constitution highlights that "the State protects the lawful rights and interests of the minority nationalities."16 Nevertheless, no "administrative codes and detailed rules for the implementation" (Bai 2004, pp. 469-70) of these minority protections were ever constructed. The Case Study will demonstrate that there is a significant disparity between the rights provided for minorities in the Chinese Constitution and the treatment of the Uyghur minority in practice in China.

While cultural genocide can manifest itself in many ways, one practice is identifiable as "forced assimilation policies towards a group" (Bilsky and Klagsbrun 2018), which, as the next section will show, has been the foundation of the Chinese approach towards the Uyghur minority throughout history. Thus, while it is the treatment of the Uyghur minority in recent years that has sparked calls of cultural genocide from the international community, the following section will outline the historical context of abuse of the Uyghur minority and their culture in China.

12 United Nations Educational, Scientific and Cultural Organisation (UNESCO). “UNESCO Convention for the Safeguarding of the Intangible Cultural Heritage." 17 October 2003.

13 United Nations Educational, Scientific and Cultural Organisation 2003, art 2.

14 The Fifth National People's Congress of the People's Republic of China. "Constitution of the People's Republic of China," implemented 4 December 1982 (amended 14 March 2004) preamble.

15 The Fifth National People's Congress of the People's Republic of China 2004.

16 The Fifth National People's Congress of the People's Republic of China 2004. 


\section{The Uyghur Minority in China}

China is often considered to be "a culturally homogenous nation-state" (Clarke 2013, p. 110), composed solely of the Han-Chinese ethnic majority. In reality, China contains numerous ethnic minorities, which often inhabit regions that were "added to China in the seventeenth and eighteenth centuries" during the expansion of the Qing empire (Rossabi 2014, p. 371).

The ethnic minority that has gained significant attention in recent years and that constitutes the focus of this article, is the Turkic-speaking, Muslim minority of the Uyghur population. The Uyghur minority, along with other Islamic minorities such as the "Kazakhs, [and] Kyrgyz" (Rossabi 2014, p. 373), primarily inhabit the region of Xinjiang, located in the north-west Chinese "borderlands" (Rossabi 2014, p. 371). The Uyghur minority attempted to secede from China with the establishment of the East Turkestan Republic in 1945, but the People's Liberation Army (the military force of the Chinese Communist Party or CCP) re-gained power over the region of Xinjiang following WWII. By 1955, the Xinjiang Uyghur Autonomous Region (hereinafter referred to as XAUR) had been established, eventually legislated for under the Law of the People's Republic of China on Regional National Autonomy, enacted in 1984 (Bai 2004, p. 450) and subsequently updated in 2001 (Bai 2004, p. 453).

Clarke noted that this re-integration of Xinjiang into the Chinese State saw the beginning of the CCP's efforts to "bind these regions, and the non-Han-Chinese peoples that inhabit them, ever closer to the 'multi-ethnic' and 'unitary' Chinese state" (Clarke 2013, pp. 115-16). The implementation of assimilationist policies targeted at the Uyghur minority is woven throughout the history of the CCP's reign in Chinese government.

(i) History of Assimilation of the Uyghur Minority

Under the infamous rule of Mao Zedong, the focus was on reducing the divide in the "Marxist-Leninist 'class struggle'" (Clarke 2013, p. 121) between that Han-Chinese majority and those from ethnic minorities. In order to achieve this aim, a number of work schemes were introduced to bridge the economic gap, including the Xinjiang Production and Construction Corps (XPCC), which used "military manpower for economic and infrastructural development" (Clarke 2013, p. 118) and the Great Leap Forward strategy. These attempts targeted at minorities, including the Uyghur population, "so as to achieve their assimilation with the Han" (Clarke 2013, p. 119) increased in the latter years of Mao's rule. The most notable was that of the Cultural Revolution, in which ethnic minorities were "rigorously attacked" (Clarke 2013, p. 120). Mao's successor, Deng Xiaoping, also led the CCP in the direction of encouraging "economic development and modernisation" (Clarke 2013, p. 121). This included increased investment in the minority autonomous regions and the encouragement of "continued Han migration" (Clarke 2013, p. 121) into those regions in order to dilute the population of the ethnic minority located there.

The leadership of $\mathrm{Hu}$ Jintao coincided with the increase in global fear in the aftermath of the events of 11 September 2001, the rise of terrorism and Islamophobia. This global climate was utilized by $\mathrm{Hu}$ Jintao and the $\mathrm{CCP}$ to justify the implementation of repressive 'strike hard' policies against the minorities in Xinjiang. It was claimed that the "separatists' and 'illegal religious activities'" (Clarke 2013, p. 123) associated with the Muslim minorities located in Xinjiang constituted the roots of terrorism. These opinions would be taken advantage of by the next CCP President, Xi Jinping, in order to introduce legislation limiting the activities of the Uyghur Muslims and further encouraging their assimilation with the majority of the Chinese population.

(ii) Legislation of Assimilation

As noted above, under the leadership of current CCP President, Xi Jinping, stricter security laws were implemented as it was alleged that China was also "exposed to increasing challenges to national security" (Cai 2017, p. 80) in the form of terrorist threats. The CCP took the opportunity of the rise of global terrorism to publicize the Muslim minorities in China, such as the Uyghur population, as the source of these 'terrorist' threats. While the National Security Law 1993 was initially implemented to protect against "'external' influence" (Cai 2017, p. 78) such as "intelligence leak or espionage" (Cai 2017, p. 79), a new National Security Law was passed by the National People's Congress in 
2015. ${ }^{17}$ This new law provides for what the CCP highlighted as the internal threats being posed to China's national security, including activities of the Uyghur minority population. This change in national security concerns from external to internal in the legislation illustrates a heightened targeting of Muslim minority activity within China in recent years. Article 2 of the new National Security Law defines 'national security' as:

"a status in which the regime, sovereignty, unity, territorial integrity, welfare of the people, sustainable economic and social development, and other major interests of the state are relatively not faced with any danger and not threatened internally or externally and the capability to maintain a sustained security status." 18

The broad scope of the definition provided in this legislation has faced criticism by the UN High Commissioner of Human Rights, Zeid Ra'ad Al Hussein. ${ }^{19}$ He stressed that there is no specific definition of what amounts to a 'threat' to this broad definition of national security. This lack of specificity "leaves the door wide open to further restrictions of the rights and freedoms of Chinese citizens, and to even tighter control of civil society by the Chinese authorities than there is already." 20 Thus, the National Security Law 2015 leaves members of the minority populations in China in a precarious position and open to accusations of presenting 'terrorist' threats to Chinese national security.

In addition, the implementation of this National Security Law 2015 was supplemented by a Counter-Terrorism Law, which targeted what the CCP deemed to be terrorist activity, with a specific focus on the Uyghur population in Xinjiang.

As noted, the 'Strike Hard' policies, "a particular type of anti-crime campaign dealing with outbreaks of crime and worrying crime trends" (Li 2016, p. 352), that had previously been implemented highlighted the targeting of the Uyghur minority population in Xinjiang before the events of the 11 September 2001. The increase in sentences for so-called "Uyghur terrorists, extremists, and separatists" (Li 2016, p. 351), founded mainly on discrimination against this Muslim minority by the Han-centric government, was the extent of Chinese anti-terrorism policies before the events of 2001.

However, once the United States declared their 'war on terror,' the Chinese government "seized the opportunity to reframe its dispute with the Uyghurs as a dimension of the global war against terrorism" (Cunningham 2012, pp. 12-13). The primary target of the CCP in this policy was the East Turkestan Islamic Movement (ETIM) (Cunningham 2012). This group of Uyghur separatists was portrayed by the CCP as possessing "direct links with bin Laden, [aspiring] to launch a 'holy war,' and [intending] to set up a theocratic Islamic state in Xinjiang" (Cunningham 2012, pp. 13-14). These allegations were reinforced by the fact that the US State Department had added the ETIM to its 'terrorist watch list' in 2002 (Cunningham 2012, p. 13).

This framing of the Uyghur community as a terrorist threat resulted in the adoption of China's "first comprehensive antiterrorism legislation" by the CCP in November 2015 (Li 2016, p. 349). This law demonstrates the same "ambiguity and broadness that may undermine civil liberties and fundamental human rights" as noticed in the National Security Law (Li 2016, p. 359). Terrorism is defined so broadly in Article 3 that "activities that may fall within the scope of legitimate religious practices in other jurisdictions are otherwise rendered as criminal acts" under this legislation ( $\mathrm{Li}$ 2016, p. 381).

It is argued that the Chinese government have "overstated" (Cunningham 2012, p. 8) the role of the ETIM in terrorism globally and many experts support this argument (Cunningham 2012, pp. 24-25). It is instead submitted that the "repression by the Chinese state" (Cunningham 2012, p. 39) of the Uyghur population has caused the radicalization of certain groups such as the ETIM.

17 Ministry of National Defence of the People's Republic of China. "National Security Law of the People's Republic of China," adopted 1 July 2015.

18 Ministry of National Defence of the People's Republic of China 2015, art 2.

19 (Office of the UN High Commissioner on Human Rights 2015).

20 (Office of the UN High Commissioner on Human Rights 2015). 
Under the Counter-Terrorism Law, the rights of members of minorities who have separatist views are restricted. This law is especially targeted at the Muslim Uyghur population and was supported in Xinjiang by additional regional legislation when the Standing Committee of the Xinjiang People's Congress "passed its own version of the Counter-Terrorism Law in August 2016."21 The regional law, colloquially known as the Anti-Extremism Regulation and formally titled XUAR's Implementing Rules on the Counter-Terrorism Law, differs from the nation-wide Counter-Terrorism Law because "it aims to prevent the spread of extremist ideas, whereas the counterterrorism law deals with terrorist acts." 22 This aim is clear in the strategies of the Anti-Extremism regulation, which include, for example, what is described as "squeezing by correct faith," 23 which involves "using correct faith to clarify the people's understanding of Islam, awaken their minds and squeeze out extremism." ${ }^{24}$ This labelling of Islamic ideals as extremist specifically targets the beliefs of the Uyghur minority and attempts to 'squeeze them out' in a policy which claims to battle the terrorism fostered by both the ideals and the minority.

In this way the Anti-Extremism regulation supplements the Counter-Terrorism law in Xinjiang by trying to reform the culture, ideology and religious practices of members of specifically Islamic minorities, such as the Uyghur minority, who the CCP suspects harbor 'terrorist' views. This is despite the fact that these alleged protectionist measures target activity which often amounts to mere expressions of or participation in different religious or cultural practices than those practiced by the Han-Chinese majority.

Furthermore, this Anti-Extremism regulation was amended in October 2018 granting the local governments the authority to establish "education, skills training and psychological institutions for people who have been affected by extremist thoughts," 25 also known as 'vocational education centres.' As will be discussed in the Case Study, it has come to light in recent times that members of the Uyghur minority have been forcibly detained in these centers and had Han-Chinese-centric education imposed upon them in order to alter their ethnicity, religion and views. This detention obviously restricts the right to liberty of the Uyghur minority, which is enshrined in Article 3 of the $\mathrm{UDHR}^{26}$ and is also a right protected under customary international law.

Thus, it can be concluded from the historical analysis of State policies, as well as the legislative changes made within the past two decades, that the assimilation of the Uyghur minority into the majority Han-Chinese way of life has always been a central aim for the CCP. Nevertheless, as extensive as previous policies targeted at the Uyghur minority may have been, the Case Study in the next section will describe how this assimilation has escalated to widespread cultural genocide in China.

\section{Case Study of China's Cultural Genocide of the Uyghur Minority}

As the previous section has illustrated, the CCP has endeavored to "integrate" the approximately 12 non-Han minority groups located in China into Chinese society since its rise to power in 1949 (Clarke 2015, p. 128). The Uyghur minority in particular has been central to this planned assimilation as Xinjiang, where the majority of the Uyghur minority reside, is China's valuable "Eurasian crossroads" (Clarke 2015, p. 128), linking the State to Russia, Mongolia, Central Asian Republics, Afghanistan and Pakistan. The economic improvement strategies put in place in Xinjiang by the CCP from 2000 onwards, such as the 'Western Development Strategy' ${ }^{\prime 27}$ and the 'Belt and Road Programme, ${ }^{\prime 28}$ were aimed at transforming Xinjiang into China's "Continental Eurasian land bridge" (Clarke 2015, p. 129) and to result in new international markets for China.

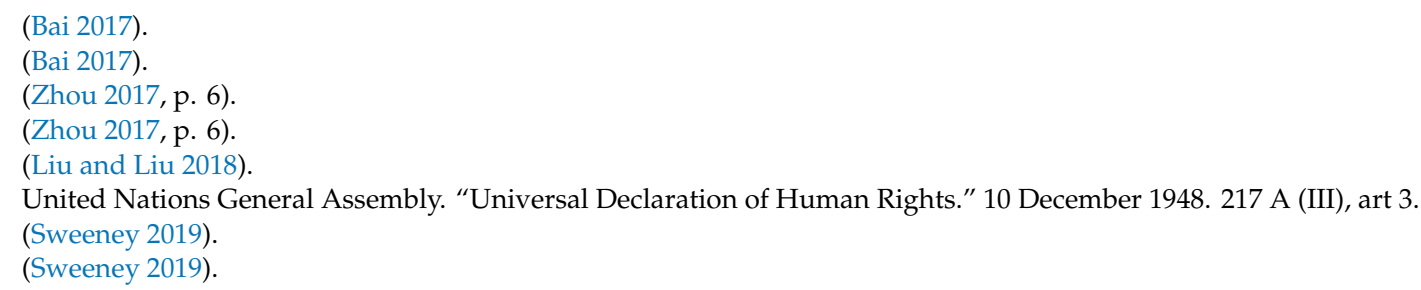


However, these plans for "repression, restriction and investment" (Clarke 2015, p. 130), labelled by the CCP as 'economic modernization,' caused further discontent among the ethnic minorities located in the Xinjiang region. The increase in economic opportunity created by these strategies attracted "members of the Han majority to migrate to the area," ${ }^{29}$ which resulted in a dilution of the minority populations there. The result was the outbreak of "periodic violence" in the Xinjiang region, which the CCP blamed on "externally inspired Islamist terrorism" among the minorities, especially the Uyghur population, as opposed to their own oppressive policy-making (Clarke 2015, p. 140). The outcome of this situation was the labelling of the Uyghur minority as the central cause of the terrorist, national security threat being posed to China and government declarations that drastic action needed to be taken.

Unlike the economic-centered assimilationist policies that had been implemented in the past, the CCP took advantage of the momentum of global fear and Islamophobia to build upon previous strategies linking the Uyghur community to terrorist activity. The result was the creation and implementation of a widespread and systematic scheme of intense cultural genocide of all aspects of the Uyghur culture; past, present and future. This on-going objective of eradicating the Uyghur culture from the valuable Xinjiang region targets and damages various aspects of the Uyghur minority, as will be discussed below.

(i) Policy of Detention in 'Vocational Education Centres'

Legislated for in the Xinjiang-specific Anti-Extremism Regulation, institutions labelled as 'vocational education centres,' were constructed and have become the 'solution' to the terrorist threat which China claims the Uyghur minority constitutes.

The CCP have chosen to deal with dissent from the Uyghur population in Xinjiang by expanding on the previous "attempts to control Uyghur religious and cultural practices" outlined above (Clarke 2015, p. 141). The most worrying of these new measures was the legalization of the establishment of 'vocational education centres' ${ }^{30}$ in the Xinjiang region. In what the CCP describes as an effective means to "stave off terrorism," ${ }^{31}$ Uyghur people are being detained and re-educated in these centers so as to make them conform to the Han-Chinese way of life. Many reasons are used by Chinese authorities to justify the need to detain a Uyghur person in re-education. For example, members of the adult Uyghur community are singled out by State police for "wearing long beards, giving up smoking or drinking, studying Arabic and praying outside mosques." ${ }^{\prime 32}$ These characteristics, associated primarily with the Islam-practicing Uyghur minority, are highlighted by the Chinese government as indicators of an extremist Islamic mentality, which when left untouched will develop into a legitimate terrorist threat. As indicated with the legislation passed by the CCP in recent years, Chinese discrimination towards the Islamic culture is encouraged by the State's highest authorities, but this targeting of Muslim minorities, especially the Uyghurs, has reached its peak with the detention of minority members in 'vocational education centres.'

The segregation of the Uyghur people from the greater Chinese community is not the only goal of these centers. Rather, as the name would suggest, members of the Uyghur community undergo extensive and systematic 're-education' throughout their detention period. This has been labelled by the Chinese government as a series of "'government-organized occupational education programs' in a 'poverty alleviation' measure" (Zenz 2019a, p. 102), which will fill the economic divide between the Uyghur minority and the majority, similar to China's previous assimilation schemes as discussed in the previous section. In addition, the Chinese government claims that this re-education is "akin to free medical treatment of a dangerous addiction to religious ideology" with respect to the Islamic faith (Zenz 2019a, p. 103). The re-education which the Uyghur detainees undergo involves studying

\footnotetext{
(Sweeney 2019).

(BBC News 2018).

(BBC News 2018).

(Ramzy and Buckley 2019).
} 
"the 'harmful' ways of religious extremism ... [replacing] their burkas ... .and [returning] 'to a secular lifestyle'" (Zenz 2019a, p. 114). Furthermore, the CCP has ensured that these vocational education centers place "increasing and significant emphasis on the learning of the Chinese language" as opposed to allowing detainees to speak their native Uyghur language (Zenz 2019a, p. 114). Thus, detention of a high percentage of the Uyghur minority population in these centers requires their denouncement of their religious beliefs, language and overall culture should they ever hope to be released back into society. The result of this "intense campaign of coercive social re-engineering" (Zenz 2019a, p. 124) is essentially the destruction of the Uyghur minority culture among its adult community-in other words, a cultural genocide.

In recent years, global awareness of the existence of these centers in Xinjiang has increased, which has resulted in widespread fear among family and friends of members of the Uyghur population that their uncontactable loved ones have been forcibly detained in these centers. A central Uyghur non-governmental organization (NGO), Uyghur Human Rights Project, has published three reports on the situation, one in October $2018^{33}$, with updates in January ${ }^{34}$ and March $2019 .{ }^{35}$ This NGO has identified that Uyghur intellectuals are a central group being targeted by the CCP in this policy of detention in 'vocational education centres.' This specific targeting of Uyghur intellectuals is evident from the numbers highlighted, with an estimated $386^{36}$ "interned, imprisoned or forcibly disappeared"37 since April 2017, of which "five deaths in custody ... have been confirmed." ${ }^{38}$ It has been highlighted that the CCP has "specifically targeted Uyghur intellectuals" 39 because they constitute "the repository of cultural and scientific knowledge of a people, and in order to break the ethnicity you need to break the ethnic life." 40 This policy of detention of intellectuals and those who could keep the Uyghur culture alive through their dissemination of Uyghur history, knowledge, religious beliefs and language clearly constitutes a part of the CCP's policy of "cultural cleansing"41 and cultural genocide.

It is suspected that this 'crackdown' against Uyghur intellectuals began long before April 2017, possibly beginning as early as 2013, when Xi Jinping was appointed as President. ${ }^{42}$ A notable pre-2017 example of CCP-imposed oppression of Uyghur intellectuals was the sentencing of Ilham Tohti to life imprisonment in 2014. The former economics professor at the Central Nationalities University in Beijing ${ }^{43}$ was accused by the Chinese government of spreading 'separatist' views, despite the fact that his colleagues confirmed that Tohti was always a supporter of Han-Uyghur relations. ${ }^{44}$ Although the UN Working Group on Arbitrary Detention found that Tohti's imprisonment was arbitrary and contrary to human rights law, ${ }^{45}$ he remains imprisoned and human rights groups have been lobbying for his release since the fifth anniversary of his arrest. ${ }^{46}$ According to the Uyghur Human Rights Project, seven of Tohti's former students were also sentenced to "up to eight years" 47 imprisonment in 2014. However, post-2017, such arbitrary imprisonments have been combined with the detention of academics in 'vocational education centres' without notice. Thus, most disappeared academics or intellectuals, some of whom will be discussed below, are presumed to have been detained in such centers.

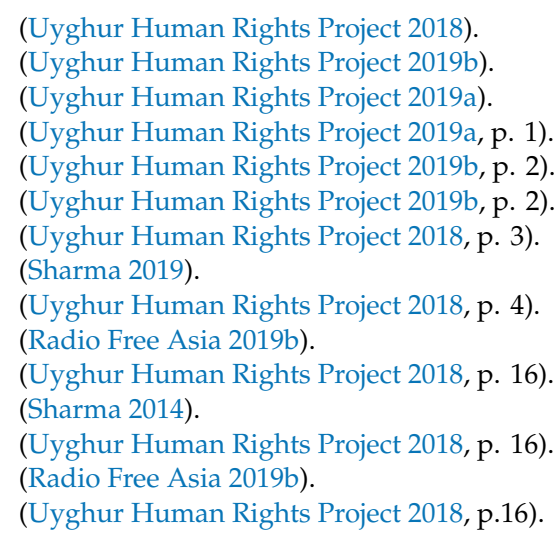


Like Tohti, Rahile Dawut was also a lecturer and "leading expert on Uyghur folklore and traditions at Xinjiang University" 48 and has not been contactable since December $2017 .{ }^{49}$ It is suspected that she has also been detained in a 'vocational education centre' in Xinjiang when there was a "purge of academics in late 2017"50 in the region. While Dawut's research "had previously been sponsored by the Chinese state, ${ }^{\prime 51}$ Dr Rachel Harris, a lecturer at the School of Oriental and African Studies at the University of London and former research colleague of Dawut, ${ }^{52}$ noted that "Uighur academics who have been researching Uighur culture, and those with international contacts have been targeted" ${ }^{\prime 53}$ by the CCP.

Alongside Dawut, it is reported that 21 other intellectuals previously employed at Xinjiang University are also being detained in 'vocational education centres, Abdukerim Rahman, Azat Sultan and Gheyretjan Osman, language professor Arslan Abdulla, ${ }^{55}$ as well as former University President, Tashpolat Tiyip. ${ }^{56}$ While Xinjiang University's "prominence in Uyghur-produced scholarship" ${ }^{\prime 57}$ has made its intellectuals a central focus for the Chinese government, Uyghur intellectuals from other universities have also been affected. For example, 13 uncontactable intellectuals previously employed by Kashgar University ${ }^{58}$ have all been erased from the Kashgar University website and their "whereabouts are unknown." ${ }^{\text {"59 }}$ A pattern has been identified by a former staff-member at Kashgar University whereby Uyghur intellectuals "disappeared from the university website as employees and then they disappeared themselves." ${ }^{\prime \prime 0}$ Once again, this pattern suggests that these Uyghur intellectuals have also been interned by the CCP in the 'vocational education centres.'

In July 2019, amidst growing global tensions regarding the detention of members of the Uyghur minority in these centers and "allegations of abuse" 61 throughout their detention periods, officials in Xinjiang reported that "most" of the detainees had left re-education and entered the workforce. While these alleged releases would be welcomed by the international community, the number of Uyghur detainees currently in the 'vocational education centres' is "over a million" 62 and thus, the actual number of releases is highly questionable. Furthermore, the "coercive ideological remoulding" 63 suffered throughout any length of detention in these 'vocational education centres' would undoubtedly cause irreparable damage to the Uyghur culture whatever the length of exposure.

Overall, the detention of Uyghur adults in these 'vocational education centres' from 2017 onwards has caused untold cultural destruction and the specific targeting of Uyghur intellectuals and academics has also halted any possible spreading of Uyghur culture through the education system. Nevertheless, the adult population of the Uyghur minority are not the only group being targeted as the CCP also have cultural genocide policies aimed at the Uyghur generations of the future.

(ii) Indoctrination of Uyghur Children

The CCP's strategized policy of cultural genocide of the Uyghur minority applies not only to the adult Uyghur population through their detention in 'vocational education centres,' but also to Uyghur children.

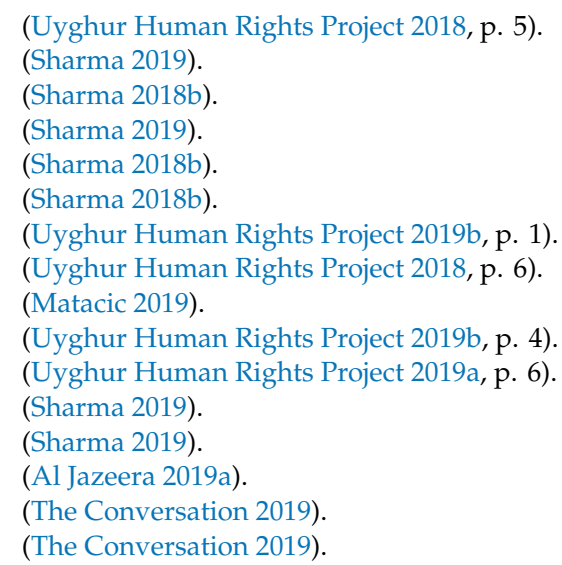


In July 2019, German researcher Adrian Zenz highlighted the fact that Uyghur children face a similar fate to their parents as State-run boarding schools have been set up to facilitate the 're-education' of the youngest members of the Uyghur minority. Soon after the campaign of 're-education' of the adult Uyghurs began, "first reports started to emerge that the children of so-called 'double-detained' parents were being placed in state care" (Zenz 2019b). This means that Uyghur children whose parents had been detained in 'vocational education centres' are being placed in the care of the Chinese government, resulting in the "intergenerational separation" of the Uyghur community as a whole (Zenz 2019b). Moreover, the government care that these Uyghur children are being placed in consists of "public boarding schools or in special children's shelters", where students, from pre-school to high-school ages, undergo "intensive, state-controlled and highly coercive Chinese language education and immersion, along with political indoctrination and psychological correction" (Zenz 2019b). Therefore, the Uyghur children are essentially undergoing the same process of cultural re-wiring as their parents and possibly with more permanent results, because with their young age of indoctrination, they will likely not recall much, if any, of their Uyghur cultural origins when they graduate. Thus, this placing of State-orphaned Uyghur children into State care is another "deliberate strategy and crucial element in the state's systematic campaign of social re-engineering and cultural genocide in Xinjiang" (Zenz 2019b).

As for the young Uyghur adults attending university, a November 2019 report by Ramzy and Buckley in the New York Times highlights that the CCP had also taken these members of the Uyghur minority into consideration in their plan. The Chinese government funds the sending of "Xinjiang's brightest young Uighurs to universities across China, with the goal of training a new generation of Uighur civil servants and teachers loyal to the party." 64 This separation of Uyghur youth from the education available in the home of their culture in Xinjiang is also combined with restrictions on Uyghur education in general, as will be elaborated on below. Thus, it was realized that it was necessary to implement a plan to inform these Uyghur university students where their detained parents were when they returned home to Xinjiang for Summer break. The CCP directed "officials to corner returning students as soon as they arrived and keep them quiet" ${ }^{\prime \prime 5}$ on the issue of their detained families. Leaked files from the Chinese government revealed that Uyghur students were informed that their family members were placed in 'vocational education centres" "for their own good" 66 and that the length of their stay in these centers would depend on the students' behavior. It is noted that this information painted "a striking picture of how the hidden machinery of the Chinese state carried out the country's most far-reaching internment campaign since the Mao era," ${ }^{\prime 67}$ one which illustrates a modern example of cultural genocide.

By targeting the youth of the Uyghur minority population, the CCP is essentially educating the next generation of Uyghurs in a way that eradicates their culture and remolds Uyghur children to the Han-Chinese way of life. Furthermore, through the carefully planned targeting of the young-adult Uyghurs, who may have formed their own cultural identity by their stage in life, the use of fear tactics coerces their silence, compliance and loyalty to the CCP. The Uyghur youth are most vulnerable to the effects of cultural genocide and thus, their specific targeting by the Chinese State evidences its clear intentions with respect to this minority population.

(iii) Restriction of Uyghur Education

Alongside the re-education of the current members of the Uyghur minority in China, efforts have also been made to ensure that future generations will not be able to educate themselves on Uyghur culture, thus completing the cycle of cultural genocide.

In addition to the constant fear of being detained in 'vocational education centres,' Uyghur intellectuals in Chinese universities are constantly at risk of losing their jobs if they deviate from

\footnotetext{
(Ramzy and Buckley 2019)

(Ramzy and Buckley 2019)

(Ramzy and Buckley 2019)

(Ramzy and Buckley 2019).
} 
the Chinese Government-approved curriculum or criticize the CCP while teaching. The number of university professors losing their positions due to exercising their free speech while teaching has increased in the past year ${ }^{68}$ and this fear is ever-present for Uyghurs in light of the significant amount of Uyghur intellectuals targeted by the policy of detention in 'vocational education centres,' as outlined above. The threats of loss of position and being identified as Uyghur to the CCP have also increased due to the fact that the CCP have recruited student informants within universities to monitor and report any academic behavior that may warrant punishment. ${ }^{69}$

A further restriction on the dissemination of Uyghur culture through education is censorship, which is commonplace in China. This practice, whereby the Chinese government prohibits the publishing or dissemination of works of which the CCP does not approve, has a long association with the extension and maintenance of the CCP's power in everyday life. For example, "outcry"70 ensued in August 2017 when Cambridge University Press removed more than 300 academic articles from its China Quarterly online journal at the request of the CCP. ${ }^{71}$ This censorship targeted articles about "sensitive topics such as ... China's Cultural Revolution ... Xinjiang"72 and constituted a "wake-up call for the global academic community"73 regarding the wide reach of the CCP's restrictive policies. While Cambridge University Press eventually responded to the uproar from scholars by reversing the effects of this censorship decision, ${ }^{74}$ fellow British academic publisher, Taylor and Francis, also proceeded to remove "more than 80 journals from its offerings in China"75 in December 2018.

Thus, through strict policies of State censorship and unfair dismissals or worse, the detention in 'vocational education centres' of Uyghur intellectuals, the Chinese government is strategically reducing the ways in which Uyghur cultural knowledge may be researched and obtained. In doing so, the $\mathrm{CCP}$ is ensuring that the Uyghur culture cannot be spread through formal education channels. It goes without saying that those who may try to keep the Uyghur culture alive through clandestine methods would inevitably face detention or a lengthy prison sentence for what the CCP would label as the spreading of unhealthy, Islamic extremism.

All of the aspects discussed above collectively display the hallmarks of cultural genocide that Lemkin outlined. The detention of Uyghurs in 'vocational education centres' exiles them from the majority population and detains them in an environment where they cannot practice their religion, speak their language or practice their culture in any way. By exiling the adults of the Uyghur minority, this leaves the children vulnerable to transfer to specific boarding schools in which they are also indoctrinated into the Han-Chinese way of life from nursery to high-school ages. Furthermore, the restriction on the academic and intellectual core of the Uyghur minority through the preventing of publications or targeted dismissals also contributes to the destruction of the future of the Uyghur culture.

Therefore, these various elements combined represent a pre-planned and systematic policy that the CCP is implementing in order to rid China of the Uyghur culture entirely. This bid of cultural genocide is widespread in its implementation and targets any Uyghur groups who could possibly maintain the existence of the Uyghur culture. The barrage of Chinese cultural brain-washing that detained Uyghur adults are subjected to aims to re-wire their cultural and religious beliefs and release pro-party citizens back into the Xinjiang region, distrusting or devoid of their former Uyghur culture.

The CCP also has specifically targeted Uyghur academics and educational institutions, through detention, loss of position or censorship. This also demonstrates the aim of the CCP to ensure the extinction of the Uyghur culture not only by re-educating current and future generations with regards

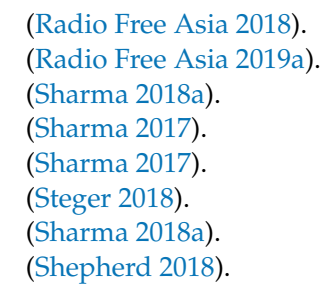


to culture, but also by destructing the ways in which the Uyghur culture could be disseminated or re-ignited in the future. This is evident in the targeting and internment of Uyghur university lecturers in Uyghur-specific areas of research and institutions and also through censoring articles on Uyghur culture from academic databases in China.

With regards to the placing of Uyghur children into boarding schools or shelters where they are indoctrinated into the Han-Chinese way of life, it is recognized that this situation has "become like the colonial boarding schools used by the United States, Canada or Australia, to assimilate native ethnic populations" (Zenz 2019b). These are instances of cultural genocide that international advocates of human rights had hoped that the world would not see again. This similar abuse of Uyghur children constitutes merely a step in the CCP's broader plan of creating an ethnically and culturally homogenous China.

In summary, while the global media is led to believe that China is battling terrorist threats internally, further analysis of the State policies and actions reveal that China is instead engaged in a battle with the Uyghur culture. The CCP claim that the construction of the 'vocational education centres' in the Xinjiang region and the other measures specifically targeted towards the Uyghur minority population are effective ways of dealing with the extremist, Islamic culture being fostered by this minority. In reality, the above examples of CCP-implemented actions reveal that this minority is instead having its culture rendered extinct at the hands of the Chinese government. With the passage of time, the cultural genocide policies have continued to exacerbate and the next section will investigate whether there is a solution to this destruction of the Uyghur minority culture.

\section{Is There Any Way Forward for the Uyghur Minority in China?}

As the above Case Study of the current plight of the Uyghur minority has shown, cultural genocide of the Uyghur culture is currently on-going in China. When the international community eventually became aware of the "mass internment strategy"76 of the CCP with regards to their "vocational education centres,' China organized a visit for international diplomats and media representatives to these centers in Xinjiang. However, this visit was highly strategized by the Chinese government in order to display the "vocational and education"77 role that these centers carry out. As a result, in July 2019, on foot of a letter from a collective of Human Rights NGOs, ${ }^{78}$ the United Nations Human Rights Council called for "'meaningful access' for 'independent international observers"'79 to the 'vocational education centres' as opposed to CCP-guided visits. However, these calls were ignored by China, and at the 74th Session of the UN General Assembly in September 2019, the Chinese Foreign Minister, Wang Yi, continued to project the façade that China's policies are in the best interests of its inhabitants, with Yi claiming in his address to the UN General Assembly that China "remains committed to sovereign rights and equality." 80 Thus, China continues to deny its cultural genocide of the Uyghur minority in the international arena. It is also evident that since the detentions of the Uyghur minority in the 'vocational education centres' are occurring "with no mention of judicial procedures," 81 the domestic legal system in China is failing to assist the Uyghur minority. This means that despite the international image being portrayed by China, recourse for the cultural genocide of the Uyghur minority has to be addressed at the international level.

As acknowledged in Section 2 of this article, cultural genocide is not an international crime under the definition of genocide in the 1948 Genocide Convention nor within the jurisdiction of the ICC. Consequently, the definition of genocide in the Rome Statute of the ICC would need to be amended in

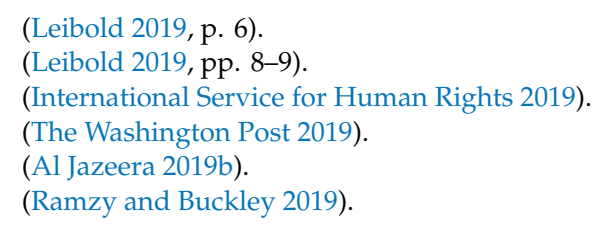


order for China's cultural genocide of the Uyghur minority to constitute an international crime. Thus, what Theriault describes as "[ $t$ ] he usual critique of narrow definitions of genocide" (Theriault 2010, p. 482 ) is highlighted as a central issue to the protection provided by the international legal framework for minorities being destroyed by cultural genocide. It was noted by Kreß that any future discussion of the definition of genocide should "revisit the drafter's decision to exclude 'cultural' genocide from the scope of the international criminalization" (Kreß 2006, p. 501). While the exclusion of cultural genocide was "the price to pay for not opening the floodgates" to the 'crime of crimes,' it is argued that it is worth reconsidering "how serious the latter risk really is" or whether the greater risk is to allow cultural genocide to continue without being criminalized (Kreß 2006, p. 501).

While discussion of the amendment of the definition of genocide has not yet arisen, the jurisprudence of the ICC and the ad-hoc criminal tribunals have become "symptomatic of a growing awareness of the limits of international law in regard to cultural genocide" (Bilsky and Klagsbrun 2018). For example, the case of Prosecutor $v$ Krstic, ${ }^{82}$ which saw the ICTY hand down its first prosecution of the crime of genocide, recognized that practices of "ethnic cleansing became genocide" 83 in the instance of Srebrenica. This is of significance because an international criminal tribunal recognized cultural genocide and its link to physical genocide, even if not granting the former the same gravity as the latter. In addition, destruction of cultural property during times of armed conflict constitutes a war crime under the jurisdiction of the ICC and in 2016, the case of Prosecutor $v$ Al Mahdi ${ }^{84}$ resulted in a sentence of 9 years for this war crime. In doing so, the court "rendered its first verdict that deals entirely with cultural destruction" (Bilsky and Klagsbrun 2018). These decisions have demonstrated that the ICC and the ad-hoc tribunals appreciate the importance of culture and recognize its destruction as a criminal offence. Furthermore, Luck highlights the fact that these decisions regarding culture have "brought the notion of cultural genocide back into the policy as well as the academic spotlight" (Luck 2018, p. 27). As was recommended at the negotiations for the Genocide Convention 1948, issues of culture and minorities have been reserved to human rights instruments, such as those discussed in Section 2; however, cultural genocide has still found no place in the international legal framework by virtue of these instruments. Nevertheless, the modern plight of the Uyghur people illustrates that cultural genocide "is showing new life seven decades after it was declared dead" (Luck 2018, p. 28). Perhaps the continued re-emergence of the atrocities of cultural genocide should now encourage attention to turn to the expansion of the definition of genocide in the international legal framework, so that action against the offending state may be taken under the Genocide Convention 1948 and the Rome Statute of the ICC.

However, even if cultural genocide was to be included in the jurisdiction of the ICC under the definition of genocide, a further challenge faces prosecuting China for the cultural genocide of the Uyghur minority. While a prosecution before the ICC would be the most preferable option in terms of accountability and retribution for the acts of cultural genocide carried out against the Uyghur minority, this situation will likely never arise. The fact that China is not "a state party to the Rome Statute of the International Criminal Court (ICC)" (O'Brien 2015, p. 535) means that China could only be brought before the ICC by referral from the United Nations Security Council. Taking into account "China's permanent member status and associated right to veto within the UNSC, an ICC referral of China would never happen" (O'Brien 2015, pp. 535-36). This unlikely possibility of ICC prosecution highlights similar political issues to those that arose in the negotiations of the 1948 Genocide Convention and once again, the politics of the international arena will ultimately decide whether China's cultural genocide of the Uyghur minority will ever amount to prosecution under the ICC. Alternatively, the situation may remain unchanged until the extinction of the Uyghur culture occurs and can never be prosecuted

82 Prosecutor v Radislav Krstic (Trial Judgment), ICTY IT-98-33-T (2 August 2002).

83 (International Criminal Tribunal for the Former-Yugoslavia Press Release 2001).

84 Prosecutor v. Ahmad Al Faqi Al Mahdi, ICC-01/12-01/15 (27 September 2016). 
because under the legal principle of nullum crimen sine lege, an action cannot be prosecuted as a crime unless it was criminalized when the action was carried out.

Therefore, the international legal framework, even if amended, would fail to protect the Uyghur minority through the conventional channels. However, the United States may have found an alternative method of pressuring China into ceasing its practices of cultural genocide against the Uyghur minority. While "few global leaders are willing to take on Beijing regarding human rights abuses," 85 in December 2019, the U.S. House of Representatives passed the Uighur Human Rights Policy Act Bill 2019. ${ }^{86}$ This bill aims to address the human rights violations committed by China against the Uyghur minority through domestic U.S. law by means of sanctions targeting Chinese government officials and if necessary, restricting the import and export market between the two States. This bill still requires the approval of the Senate and President Trump and would only function in U.S. domestic law, but, nonetheless, sends a powerful message to the global community. Furthermore, due to China's need "to trade globally, in order to achieve sustainable economic growth" (Moynihan 2017, p. 9), the loss of trade with the U.S. could be a sufficient enough incentive to convince the CCP to stop the cultural genocide of the Uyghur minority.

It is important to note that the fact that this proposed legal work-around presents the only option currently available for intervention in China's cultural genocide of the Uyghur minority does not negate the continuing need to expand the definition of genocide to include cultural genocide. The Case Study in Section 5 describes the undeniable cultural genocide of a minority, which would slip through the lacuna in the international legal framework regardless of the State in which it occurs. While the above-mentioned creative legal proposal by the U.S. constitutes the only hope for the Uyghur minority due to China's lack of participation in international law, the protection of other minorities should not be ignored. If anything, the current destruction of the Uyghur minority culture should be an incentive to prevent similar atrocities in the future. It was proposed that "a good definition of genocide must be open enough ... to accommodate the full range of past events of genocide" (Theriault 2010, p. 513). In light of cultural genocides that have occurred in the past, such as that of the Maya in Guatemala (Maguire 2018, p. 4) and the indigenous First Nations in Canada (Maguire 2018, p. 10); the international momentum and recognition that the case of the Uyghur minority has received bolsters the argument for re-opening the discussion on the inclusion of cultural genocide into the definition of genocide in both the 1948 Genocide Convention and the Rome Statute of the ICC.

In summary, the hope for the Uyghur minority in China rests in the hands of the U.S. and the enactment of their creative legislation; or, alternatively, an uptake of a similar mantle by other trading-partner States of China. In the meantime, it is noted that the cultural re-wiring of the Uyghur population to that of CCP-loyal, Chinese citizens will "take many generations" to take effect (Davidson 2012, p. 107). While the current strategy is dangerously widespread and systematic, it is noted that China's other "indigenous peoples have managed to continue to exert some level of centrifugal force to counter the central gravitational pull of Han culture and CCP ideology" (Davidson 2012, p. 107), and hopefully, this will also be the case for the Uyghur minority. Nevertheless, the absence of cultural genocide from the internationally-recognized definition of genocide has arguably persisted through the destruction of too many minority cultures. The Case Study of the Uyghur minority in China should emphasize that while sufficient access to accountability and prosecution cannot be granted to all minorities suffering cultural genocide, it should be made available to those who could avail of it and assist in the prevention of the State-imposed extinction of minority groups and cultures.

85 (Leibold 2019).

86 (BBC News 2019). 


\section{Conclusions}

In this article, Section 2 established that the definition of genocide enshrined in international law does not extend to the prohibition of cultural genocide, which, as Section 3 illustrated, poses a significant danger to the culture integral to the continued existence of minority groups. One such group is that of the Uyghur minority in China who, as demonstrated in Section 4, have historically been subject to assimilationist policies from the Han-Chinese government. The Case Study in Section 5 illuminated how this persecution has been escalated to a widespread and systematic policy of cultural genocide being imposed upon the Uyghur minority in order to eradicate the Uyghur culture in China. The options available to the international community to help end this cultural genocide are limited, as highlighted in Section 6, but even if the expansion of the definition of genocide to include cultural genocide may not be an immediate solution for the Uyghur minority, their current experience should serve to highlight that this step is necessary to offer protection to other minority groups in the future.

The findings of this article have resulted in the conclusion that the absence of cultural genocide from the internationally-accepted definition of genocide means that there is a significant gap in the international legal framework with regards to the protection of minorities. While current minority rights instruments impose obligations on States, the lack of an international criminal prosecution facing those guilty of implementing policies of cultural genocide against minority cultures does little to dissuade the practice. Consequently, cultural genocide currently presents a serious threat to minorities such as the Uyghur minority in China, especially those located in States that do not tend to recognize their international legal obligations. China's human rights record has historically been questionable, but the current cultural genocide of the Uyghur minority culture, as outlined in the Section 5 Case Study, grows increasingly concerning on a daily basis.

As explained in Section 6, the inclusion of cultural genocide into the international legal framework would be of little assistance to the Uyghur minority, because China's strong position on the international arena and limited interaction with international law means that an international criminal prosecution against Chinese heads of State is highly unlikely. Thus, the fate of the survival of the Uyghur culture rests on the political will and creative legislation of trading partners of China, such as the United States.

Nevertheless, just because the international legal framework, legislatively and politically, has failed the Uyghur minority thus far does not mean that inaction should continue with regards to the concept of cultural genocide as yet another minority group nears its extinction at the hands of State-orchestrated practices. The central conclusion to be drawn from the analysis of this article is that the Case Study of the Uyghur minority should not remain a cautionary tale of the insufficiency of the international framework in protecting minority cultures. Instead, it should become a tale that incited the legislative change that addressed the void that past victims of cultural genocide have been waiting to be filled.

Funding: This research received no external funding.

Conflicts of Interest: The author declares no conflict of interest.

\section{References}

\section{Primary Sources}

Legislation:

Universal Declaration of Human Rights 1948;

Convention on the Prevention and Punishment of the Crime of Genocide 1948;

International Covenant on Economic, Social and Cultural Rights 1966;

International Covenant on Civil and Political Rights 1966;

UNESCO Convention Concerning the Protection of the World Cultural and Natural Heritage 1972;

Constitution of the People's Republic of China 1982;

Law of the People's Republic of China on Regional National Autonomy 1984;

National Security Law of the People's Republic of China 1993; 
Rome Statute of the International Criminal Court 1998;

UNESCO Universal Declaration on Cultural Diversity 2001;

UNESCO Convention for the Safeguarding of the Intangible Cultural Heritage 2003;

National Security Law of the People's Republic of China 2015;

Counter-Terrorism Law of the People's Republic of China 2015;

Case Law:

Prosecutor v Radislav Krstic (Trial Judgment), ICTY IT-98-33-T (2 August 2002).

Prosecutor v. Ahmad Al Faqi Al Mahdi, ICC-01/12-01/15 (27 September 2016).

United Nations General Assembly Resolution N.D.

United Nations General Assembly. "The Crime of Genocide." A/RES/96. 11 December 1946.

\section{Secondary Sources}

Al Jazeera. 2019a. China: Most People in Xinjiang Camps Have 'Returned to Society'. July 30. Available online: https://www.aljazeera.com/news/2019/07/china-defends-controversial-education-centres-uighurs190730053648154.html (accessed on 20 November 2019).

Al Jazeera. 2019b. UN General Assembly 2019: All the Latest Updates. September 30. Available online: https://www.aljazeera.com/news/2019/09/hold-general-assembly-2019-latest-updates190916224113531.html (accessed on 14 December 2019).

Bai, Guimei. 2004. The International Covenant on Civil and Political Rights and the Chinese Law on the Protection of the Rights of Minority Nationalities. Chinese Journal of International Law 3: 441-70.

Bai, Tiantian. 2017. Xinjiang to Launch Anti-Extremism Regulation. The Global Times. March 9. Available online: http://www.globaltimes.cn/content/1036950.shtml (accessed on 27 November 2019).

BBC News. 2018. Xinjiang Official Defends ‘Education Centres' for Uighur Muslims. October 16. Available online: https://www.bbc.com/news/world-asia-china-45872356 (accessed on 25 March 2019).

BBC News. 2019. China Sanctions: US House Passes Bill over Treatment of Uighurs. December 4. Available online: https://www.bbc.com/news/world-us-canada-50653864 (accessed on 14 December 2019).

Bilsky, Leora, and Rachel Klagsbrun. 2018. The Return of Cultural Genocide? European Journal of International Law 29: 373-96. Available online: https://academic.oup.com/ejil/article/29/2/373/5057075 (accessed on 20 November 2019). [CrossRef]

Cai, Congyan. 2017. Enforcing a New National Security? China's National Security Law and International Law. Journal of East Asia and International Law 10: 65-89. [CrossRef]

Clarke, Michael. 2013. Ethnic Separatism in the People's Republic of China History, Causes and Contemporary Challenges. European Journal of East Asian Studies 12: 109-33. [CrossRef]

Clarke, Michael. 2015. China and the Uyghurs: The "Palestinization" of Xinjiang? Middle East Policy 22: 127-46. [CrossRef]

Cunningham, Christopher P. 2012. Counterterrorism in Xinjiang: The ETIM, China and the Uyghurs. International Journal on World Peace 29: 7-50.

Davidson, Lawrence. 2012. Cultural Genocide. Nuevo Brunswick: Rutgers University Press.

Hon, Kristina. 2013. Bringing Cultural Genocide in by the Backdoor: Victim Participation at the ICC. Senton Hall Law Review 43: 1-54.

International Criminal Tribunal for the Former-Yugoslavia Press Release. 2001. Radislav Krstic Becomes the First Person to be Convicted of Genocide at the ICTY and Is Sentenced to 46 Years Imprisonment. August 2. Available online: https://www.icty.org/en/press/radislav-krstic-becomes-first-person-be-convicted-genocideicty-and-sentenced-46-years (accessed on 20 November 2019).

International Service for Human Rights. 2019. HRC 40: High Time for a Resolution Calling for Access, Accountability in China. January 30. Available online: https://www.ishr.ch/news/hrc40-high-time-resolutioncalling-access-accountability-china (accessed on 2 April 2019).

Kennedy, Rónán. 2016. Doctrinal Analysis: The Real 'Law in Action in Cahillane. In Legal Research Methods: Principles and Practicalities. Edited by Laura Cahillane and Jennifer Schweppe. Dublin: Clarus Press.

Kreß, Claus. 2006. The Crime of Genocide under International Law. International Criminal Law Review 6: 461-502. [CrossRef] 
Leibold, James. 2019. The Spectre of Insecurity: The CCP's Mass Internment Strategy in Xinjiang. China Leadership Monitor. March 1. Available online: https://www.prcleader.org/leibold (accessed on 25 November 2019).

Lemkin, Raphael. 1944. Axis Rule in Occupied Europe. New York: Columbia University Press.

Li, Enshen. 2016. China's New Counterterrorism Legal Framework in the Post-2001 Era: Legal Development, Penal Change, and Political Legitimacy. New Criminal Law Review 19: 344-81. [CrossRef]

Liu, Caiyu, and Xuanzun Liu. 2018. Xinjiang Revises its Anti-Extremism Regulation. The Global Times. October 10. Available online: http://www.globaltimes.cn/content/1122492.shtml (accessed on 27 November 2019).

Luck, Edward C. 2018. Cultural Genocide and the Protection of Cultural Heritage. Journal Paul Getty Trust Occasional Papers in Cultural Heritage Policy 2: 1-36.

Maguire, Gerard J. 2018. A Genocide by Any Other Name: Cultural Genocide in the Context of Indigenous Peoples and the Role of International Law. Strathclyde Law Review 4: 1-24.

Matacic, Catherine. 2019. 'There's no Hope for the Rest of Us.' Uyghur Scientists swept up in China's Massive Detentions. Science Mag. October 10. Available online: https://www.sciencemag.org/news/2019/10/there-sno-hope-rest-us-uyghur-scientists-swept-china-s-massive-detentions (accessed on 25 November 2019).

Moynihan, Harriet. 2017. China's Evolving Approach to International Dispute Settlement. London: Chatham House The Royal Institute of International Affairs.

Negri, Stefania. 2013. Cultural Genocide in International Law. Transnational Dispute Management 10: 1-9.

Novic, Elisa. 2016. The Concept of Cultural Genocide: An International Law Perspective. New York: Oxford University Press.

O’Brien, Melanie. 2015. Classifying Cultural and Physical Destruction: Are Modern Historical and Current Human Rights Violations in China: Violations of Criminal Law? Criminal Law Forum 26: 533-63. [CrossRef]

Office of the UN High Commissioner on Human Rights. 2015. UN Human Rights Chief Says China's New Security Law is too Broad, too Vague. July 7. Available online: https://www.ohchr.org/en/NewsEvents/Pages/ DisplayNews.aspx?NewsID=16210\&LangID=E (accessed on 27 November 2019).

Radio Free Asia. 2018. University in China's Chongqing Demotes Professor over Comments Made in Class. March 29. Available online: https://www.rfa.org/english/news/china/professor-demotion-03292019135331.html (accessed on 27 November 2019).

Radio Free Asia. 2019a. Chinese Universities Ordered to Spy on Staff, Students in Ideological Crackdown. April 8. Available online: https://www.rfa.org/english/news/china/universities-04082019144318.html (accessed on 27 November 2019).

Radio Free Asia. 2019b. Rights Groups Demand Release of Uyghur Professor Ilham Tohti on Fifth Anniversary of Arrest. January 15. Available online: https://www.rfa.org/english/news/uyghur/tohti-01152019161310.html (accessed on 25 March 2019).

Ramzy, Austin, and Chris Buckley. 2019. The Xinjiang Papers: 'Absolutely No Mercy': Leaked Files Expose How China Organized Mass Detentions of Muslims. The New York Times. November 16. Available online: https://www.nytimes.com/interactive/2019/11/16/world/asia/china-xinjiang-documents.html (accessed on 20 November 2019).

Rossabi, Morris. 2014. A History of China. West Sussex: John Wiley and Sons Ltd.

Seifert, Charles C. 1938. The Negro's or Ethiopian's Contribution to Art. Baltimore: Black Classic Press.

Sharma, Yojana. 2014. Condemnation of Uighur Scholar's Jail Sentence. University World News. September 24. Available online: https://www.universityworldnews.com/post.php?story=20140924101427969 (accessed on 27 November 2019).

Sharma, Yojana. 2017. China Pressures Respected Journal to Censor Articles. University World News. August 18. Available online: https://www.universityworldnews.com/post.php?story=20170818171745234 (accessed on 27 November 2019).

Sharma, Yojana. 2018a. Overseas China Scholars Face Self-Censorship Dilemma. University World News. August 24. Available online: https://www.universityworldnews.com/post.php?story=20180824153912431 (accessed on 27 November 2019).

Sharma, Yojana. 2018b. Scholars Targeted as Uighur Purge Engulfs Universities. University World News. September 28. Available online: https://www.universityworldnews.com/post.php?story=20180928160408284 (accessed on 27 November 2019). 
Sharma, Yojana. 2019. Uyghur Scholars and Students Interned or Disappeared. University World News. January 30. Available online: https://www.universityworldnews.com/post.php?story=20190130134847307 (accessed on 27 November 2019).

Shepherd, Christian. 2018. British Publisher Pulls Academic Journals from China after Government Complaint. Reuters. December 24. Available online: https://www.reuters.com/article/us-china-censorship/britishpublisher-pulls-academic-journals-from-china-after-government-complaint-idUSKCN1ONOIY (accessed on 27 November 2019).

Steger, Isabella. 2018. A New Study Shows the Growing Perils for Academics Researching China. Quartz. September 5. Available online: https:/qz.com/1379245/study-of-academic-freedom-in-china-shows-perilsfor-researchers/ (accessed on 27 November 2019).

Sweeney, Pete. 2019. Breaking Views-Xinjiang is an Extreme Case of China's Growth Woes. Reuters. January 30. Available online: https://www.reuters.com/article/uk-china-economy-breakingviews/breakingviewsxinjiang-is-an-extreme-case-of-chinas-growth-woes-idUSKCN1PO0J8 (accessed on 27 November 2019).

The Conversation. 2019. Despite China's Denials, Its Treatment of Uyghurs should be Called What It Is: Cultural Genocide. July 24. Available online: https://theconversation.com/despite-chinas-denials-its-treatment-ofthe-uyghurs-should-be-called-what-it-is-cultural-genocide-120654 (accessed on 25 November 2019).

The Washington Post. 2019. Muslim Countries Joined China in Defending Its Cultural Genocide of Uighurs, Aren't they Ashamed? July 20. Available online: https:/www.washingtonpost.com/opinions/global-opinions/ muslim-countries-joined-china-in-defending-its-cultural-genocide-of-uighurs-arent-they-ashamed/2019/ 07/20/0a7d62b4-aa3f-11e9-86dd-d7f0e60391e9_story.html (accessed on 25 November 2019).

Theriault, Henry C. 2010. Genocidal Mutation and the Challenge of Definition. Metaphilosophy 41: 481-524. [CrossRef]

Uyghur Human Rights Project. 2018. The Persecution of the Intellectuals in the Uyghur Region: Disappeared Forever? October. Available online: https://docs.uhrp.org/pdf/UHRP_Disappeared_Forever_.pdf (accessed on 27 November 2019).

Uyghur Human Rights Project. 2019a. Detained and Disappeared: Intellectuals Under Assault in the Uyghur Homeland. March. Available online: https://docs.uhrp.org/pdf/Detained-and-Disappeared-IntellectualsUnder-Assault-in-the-Uyghur-Homeland.pdf (accessed on 27 November 2019).

Uyghur Human Rights Project. 2019b. The Persecution of the Intellectuals in the Uyghur Region Continues. January. Available online: https://docs.uhrp.org/pdf/UHRP_UPDATE-ThePersecution_ofTheIntellectuals-inthe-Uyghur-Region.pdf (accessed on 27 November 2019).

Zenz, Adrian. 2019a. Thoroughly reforming them towards a healthy heart attitude: China's political re-education campaign in Xinjiang. Central Asian Survey 38: 102-28. [CrossRef]

Zenz, Adrian. 2019b. Break Their Roots: Evidence for China's Parent-Child Separation Campaign in Xinjiang. The Journal of Political Risk 7. Available online: http://www.jpolrisk.com/break-their-roots-evidence-for-chinasparent-child-separation-campaign-in-xinjiang/ (accessed on 26 November 2019).

Zhou, Zunyou. 2017. Chinese Strategy for De-radicalization. Terrorism and Political Violence, June 9. [CrossRef]

(C) 2020 by the author. Licensee MDPI, Basel, Switzerland. This article is an open access article distributed under the terms and conditions of the Creative Commons Attribution (CC BY) license (http://creativecommons.org/licenses/by/4.0/). 